\title{
Dental Asymmetry in a Late Archaic and Late Prehistoric Skeletal Sample of the Ohio Valley Area
}

\author{
Paul W. Sciulli* \\ Department of Anthropology, The Ohio State University, Columbus, Ohio 43210
}

\begin{abstract}
Dental asymmetry (directional, antisymmetry, and fluctuating) is analyzed in samples from two prehistoric Native American populations: a terminal Late Archaic population (3200-2700 BP) and a Late Prehistoric population (ca. 750 BP). Both directional and fluctuating asymmetry were found in each sample. Directional asymmetry occurs in only four teeth in the Late Archaic sample and in two teeth in the Late Prehistoric sample. Neither sample exhibits the tendency for opposing arch dominance in directional asymmetry. Fluctuating asymmetry is significantly greater than measurement error for all teeth in each sample. However, contrary to expectations the Late Prehistoric maize agriculturists do not show an overall greater degree of fluctuating asymmetry compared
\end{abstract}

Developmental stability is the result of processes that act to insure that features of organisms differentiate, grow, and mature along their genetically predetermined pathways (Waddington, 1957). Two primary hypotheses have been offered to explain the genetic basis of developmental stability: the heterozygosity and the genomic coadaptation hypotheses. The heterozygosity hypothesis proposes that developmental stability is augmented by increasing heterozygosity. The mechanism for increased stability with increased heterozygosity may be greater biochemical efficiency (Mitton, 1994) or an increase in the range over which metabolic functions can be performed (Watt, 1983). The genomic coadaptation hypothesis proposes that developmental stability results from the action of natural selection which establishes and maintains complex genetic interactions, a genetic balance, over the evolutionary history of taxa (Dobzhansky, 1970; Mather, 1973). Recently it has been shown that heat-shock protein 90 (Hsp90), an essential and abundant protein at normal temperatures and induced by stress in all eukaryotes tested,buffers developmental stability against stochastic processes (Queitsch et al., 2002). Hsp90 normally acts to reduce the likelihood that stochastic events will alter the deterministic path of developmental programs by chaperoning metastable proteins and stabilizing them in conformations that allows them to be activated in the proper time and place (Queitsch et al., 2002).

Hybridization, according to the heterozygosity hypothesis, is expected to increase developmental stability while the genomic coadaptation hypothesis would predict reduced stability from hybridization. In some cases of hybridization between subspecies to their forager ancestors. This result coupled with a survey of pathological conditions in these populations suggest that stress levels in Ohio Valley populations, at least that stress which affected dental developmental stability, were not drastically increased with the introduction of maize agriculture. Spearman correlations between relative tooth size variation (coefficient of variation), the magnitude of fluctuating dental asymmetry, and duration of time (per tooth) spent in soft tissue development were obtained for each sample. Coefficients of variation and fluctuating asymmetry are significantly correlated in both samples but fluctuating asymmetry is significantly correlated with duration of soft tissue development only in the Late Prehistoric population.

increased developmental stability for some features has been found (Ailbert et al., 1997; Freeman et al., 1995). Generally however developmental stability appears to decrease when coadapted gene complexes are disrupted (Graham, 1992) with the effect on developmental stability modified by the degree of divergence between the hybridizing taxa and the recency of hybridization (Markow and Ricker, 1991). Hsp90 may also be affected by increased polymorphism. While Hsp90 buffers the expression of genetic variation, extensive polymorphism in genomes may exceed Hsp90's ability to maintain functional developmental pathways resulting in reduced stability or altered features (Queitsch et al., 2002).

In addition to genetic causes environmental factors may affect developmental stability (Waddington, 1960; Siegel and Doyle, 1975a; 1975b; 1975c; Hurtado et al., 1997). Environmental stress is hypothesized to reduce developmental stability by decreasing the ability of organisms to buffer against developmental noise or by increasing developmental noise by increasing intracellular stress (Hochwender and Fritz, 1999; Queitsch et al., 2002).

Reduced developmental stability can be measured by the analysis of fluctuating asymmetry (Parsons, 1990; Clarke, 1992; Graham et al., 1993; Woods et al., 1998; Nosil and Reimchen, 2001). Fluctuating asymmetry (FA), the variance in random deviations from exact bilateral symmetry, is considered a

*Correspondence to: Paul W. Sciulli, Department of Anthropology, The Ohio State University, Columbus, Ohio 43210. E-mail: Sciulli.1@osu.edu 
measure of developmental stability because the sides of bilaterally symmetrical organisms share the same genotype and environmental differences between the sides, summed over development, are likely to be small. The differences between features from the sides of organisms can then be attributed primarily to random errors that accumulated in development (Klingenberg and Nijhout, 1999). A large accumulation of random errors in development will lead to greater magnitudes of FA and indicate reduced developmental stability.

Although there is substantial support for the hypothesis that increased environmental stress leads to increased FA (Parsons, 1990) some studies have found no association between FA and increased stress (see Palmer and Strobleck, 1986). This situation occurs particularly for studies of environmental stress in natural (non-experimental) populations. This inconsistency may arise because natural environmental perturbations were not severe enough (compared to experimental manipulations of environment) to affect FA and because not all features respond to stress in the same manner. Response to a given type of stress may be feature specific and some features may not be reliable indicators of increased environmental stress (Parsons, 1990; Woods et al., 1998).

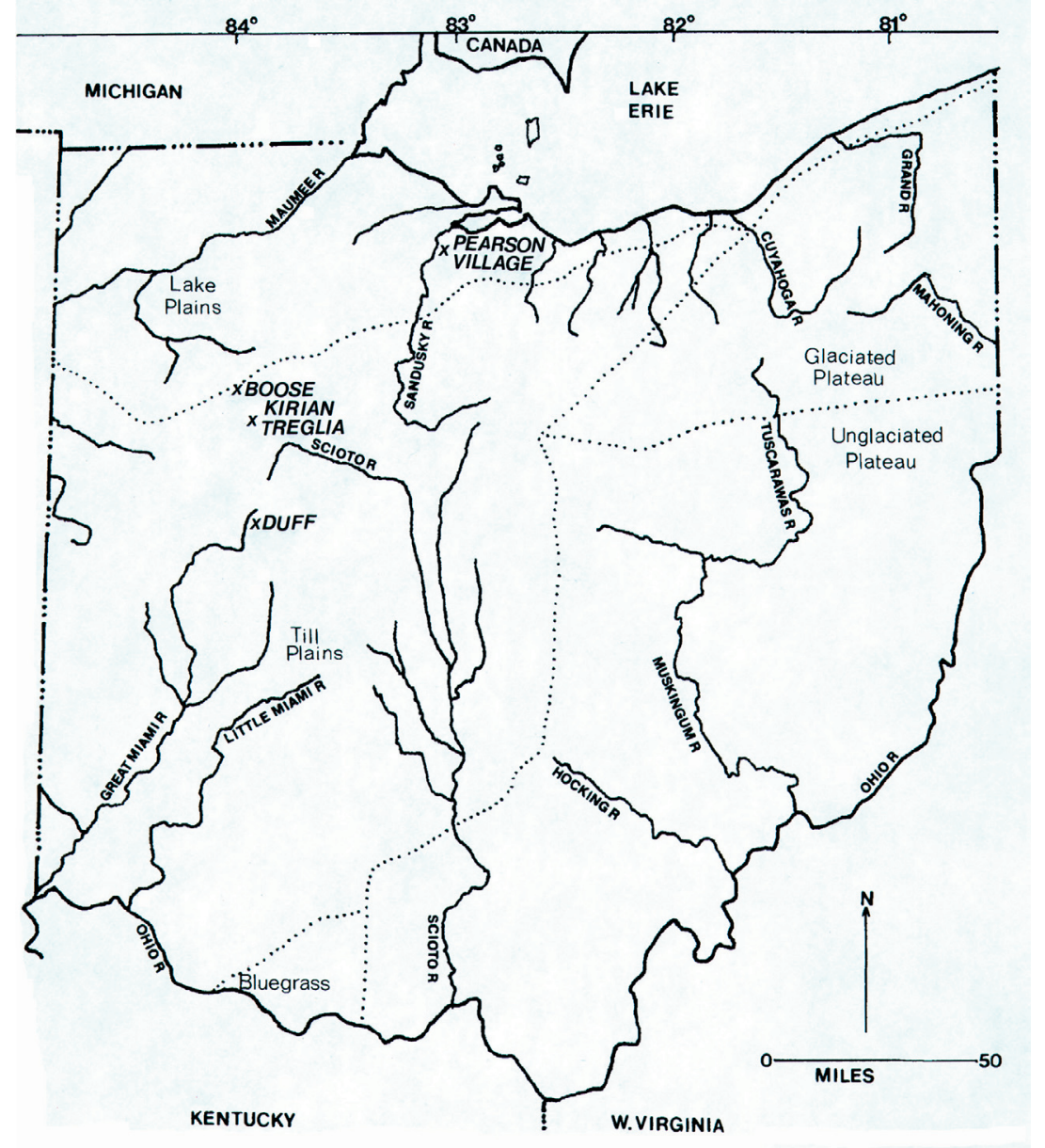

Fig. 1. Map of Ohio showing locations of Late Archaic (Boose, Kirian, Treglia, and Duff) and the Late Prehistoric Pearson Village sites.
While all features in organisms may not reflect increased stress by the analysis of FA, the human dentition does appear to be a reliable indicator if levels of stress are relatively high and sample sizes are adequate (Parsons, 1990). Variation in FA among both living and prehistoric human groups have provided indirect evidence of variation in developmental stability (Bailit et al., 1970; Doyle and Johnston, 1977; Perzigian, 1977; DiBernanardo and Bailit, 1978; Townsend and Brown, 1980; Harris and Nweeia, 1980; Townsend, 1981; Kieser et al., 1986; Mizoguchi, 1986; Kieser and Groeneveld, 1988).

The purpose of the present study is to compare levels of fluctuating dental asymmetry in samples of two prehistoric Native American populations from the Ohio Valley region. The populations represent an evolving lineage (Sciulli and Oberly, 2002) with one population extant during the Late Archaic period (ca. 3200-2700 BP) and the second extant during the Late Prehistoric period (950-300 BP). The earlier Late Archaic population subsisted primarily as hunter-gatherers while the Late Prehistoric population practiced maize agriculture. The transition to agriculture is associated with an inferred decline in general health status for many prehistoric populations (Cohen and Armelagos, 1984; Cook, 1984; Cohen, 1989; Larsen, 1995; Steckel and Rose, 2002). This inference is based on the general increase in prevalence of skeletal and dental lesions found in agricultural populations compared to their forager ancestors and is hypothesized to have resulted from an increase in physiological stress due to a reduction in the quality of the diet, an increased prevalence of infectious disease (due to crowding), and the synergistic effects of poor diet and diseases (Goodman and Armelagos, 1989; Larsen, 1995). Thus based on this hypothesis the Late Prehistoric maize agriculturalists are expected to show higher levels of FA compared to their Late Prehistoric forager ancestors.

The amount of FA as well as relative size variation have been found to be associated with the duration of the pre-calcification stage of tooth development (Mizoguchi, 1980; Farmer and Townsend, 1993; Townsend and Farmer, 1998). The present study will, in addition to the comparisons of FA, review the potential associations among these variables both within and between the samples. 


\section{MATERIAL AND METHODS}

\section{Samples}

Two samples are used in the present study: Late Archaic and Late Prehistoric. The Late Archaic sample is derived from a population that was distributed in northwestern Ohio and composed of slightly differentiated subpopulations among which differentiation was related to the geographical dispersion of the subpopulations. The minimum $\mathrm{F}_{\mathrm{ST}^{\prime}}$ a measure of population divergence, for Late Archaic subpopulations is 0.039 , similar in magnitude to $F_{S T}$ values found for more recent Eastern Woodlands subpopulations (Jantz and Meadows, 1995; Rangdon, 1995; Tatarek and Sciulli, 2000).

Habitation sites of the Late Archaic subpopulations have yet to be discovered and archaeological data relating to subsistence-settlement patterns are thus lacking. Analysis of dental disease and stable carbon isotope ratios, however, have shown that Late Archaic subpopulations exhibited patterns of these diet indicators similar to hunting-gathering populations (Sciulli, 1997). Archaeological data from neighboring regions suggest that Late Archaic subpopulations subsisted by hunting-gathering with the probable inclusion of some native domesticated plants to the diet (Smith, 1989; 1995).

Three Late Archaic subpopulations are used in this study to represent the Late Archaic population: Boose (Sciulli and Schuck, 2001), Kirian Treglia (Sciulli et al., 1993), and Duff (Sciulli and Aument, 1987). These subpopulations are used because preservation was good, individuals were fairly complete, each sex was represented, and these were the largest subpopulations available. A total of 54 Late Archaic adults (18-35 years) comprise the sample with an equal number of males and females.

The Late Prehistoric sample studied here is from the Sandusky Tradition, Pearson Village. A total of 86 adults, 43 males and females, are sampled from the Middle cemetery (Sciulli et al., 1996). The Middle cemetery is associated with the North Pearson Village (ca. $750 \mathrm{BP}$ ) which was a late spring to early fall base camp at which maize agriculture was a primary subsistence activity (Bowen, 1978; Stothers and Abel, 1989). Faunal and floral analyses have shown that hunting, fishing, and gathering also contributed significantly to the subsistence of this population (Bowen, 1991). The settlement pattern of the Pearson Village population was characterized by spring to fall village occupation and winter dispersal to small extractive camps (Strothers and Abel, 1989).

Analysis of Late Prehistoric population structure in the Ohio Valley region has shown that subpopulations were somewhat more differentiated than in the Late Archaic $\left(\mathrm{F}_{\mathrm{ST}}=0.078\right)$ and that genetic differentiation was not related to the pattern of geographic dispersion of subpopulations. It has been hypothesized that the difference in population structure between the Late Archaic and Late Prehistoric populations was due to the increased pace of cultural change in the Late Prehistoric period related to the introduction of tropical domesticates (maize, beans) and increased population growth (Tatarek and Sciulli, 2000).

Procedures for estimating age and sex for the Late Archaic and Pearson Village samples can be found in Sciulli and Aument (1987) and Sciulli et al. (1996) respectively.

\section{Measurement}

The bucco-lingual (BL) diameters of permanent antimetric teeth present in each individual were measured except for the third molars. The BL diameters are the distances between points of maximum curvature of the buccal and lingual surfaces of a tooth. Each tooth was measured twice with time intervals between measures ranging from three weeks to four months. Teeth with excessive wear or lesions which affected the BL diameter were not used. Measurement of the Late Archaic sample was done with a Helios dial caliper (instrument accuracy $\pm 0.05 \mathrm{~mm}$ ) and measurement of the Pearson Village sample was done with a Mitutoyo Digimatic caliper (instrument accuracy $\pm 0.02 \mathrm{~mm}$ ).

\section{Statistical Analyses}

Preliminary analyses of the data consisted of obtaining descriptive statistics (mean, coefficient of variation, and a normality measure) and a measurement error determination for each tooth measure in both samples. Measurement error is determined as $\Sigma \mid R_{i}-$ $\mathrm{L}_{\mathrm{i}} \mid / \mathrm{n}$, where $\mathrm{R}$ and $\mathrm{L}$ are the diameters of the right and left sides, $i$ is the measure ( 1 or 2$)$, and $n$ is the sample size.

The distributions of $\left(\mathrm{R}_{\mathrm{i}}-\mathrm{L}_{\mathrm{i}}\right)$ were tested for size dependence, anti-symmetry, and directional asymmetry. To test for size dependence plots of $\left(\mathrm{R}_{\mathrm{i}}-\mathrm{L}_{\mathrm{i}}\right)$ against a size measure $\left(\mathrm{R}_{\mathrm{i}}-\mathrm{L}_{\mathrm{i}}\right) / 2$, were obtained. Although there was no evidence of size dependence for $\left(\mathrm{R}_{\mathrm{i}}-\mathrm{L}_{\mathrm{i}}\right)$ all measures were transformed by dividing the $\left(\mathrm{R}_{\mathrm{i}}-\mathrm{L}_{\mathrm{i}}\right)$ by the size measure for the analysis of variance (see below).

Anti-symmetry occurs when a structure in a groups of organisms is normally asymmetric but the side which has a greater development is variable (Van Valen, 1962). In extreme cases this will yield a bimodal distribution of the signed differences between the sides. In less extreme cases the distribution of signed differences will tend toward platykurtosis or possibly leptokurtosis if there is anti-symmetry only for larger deviations from equality (Van Valen, 1962). Although anti-symmetry has not been reported for the human dentition the distributions of $\left(\mathrm{R}_{\mathrm{i}}-\mathrm{L}_{\mathrm{i}}\right)$ in the present samples were tested for departures from normality both graphically and numerically. 
Directional asymmetry occurs when there is a greater development of a feature on one side of an organism than the other side (Van Valen, 1962). The distribution of signed differences about the mean is generally normal but the mean is significantly greater or less than zero depending on which side shows the greater development. Recently directional asymmetry has been noted in both the deciduous (Townsend and Farmer, 1998) and permanent (Harris, 1992) dentitions of human populations. For the present samples the means of the distributions of sized differences between the sides are tested for differences from zero. In addition, directional asymmetry is tested in the analysis of variance (see below).

The analysis of fluctuating dental asymmetry employed a two-way, mixed model analysis of variance (sides fixed, individuals random) with repeated measurements for each side (Palmer and Strobeck, 1986). The model is presented in Table 1 , where $S$ is the number of sides $(S=2)$, J is the number of individuals, and $\mathrm{M}$ is the number of measures per side $(\mathrm{M}=2)$. This analysis cannot partition out anti-symmetry (the variance components of fluctuating asymmetry and antisymmetry are contained in the non-directional variance component). However, the presence of anti-symmetry is tested in the evaluation of the $\left(R_{i}-L_{i}\right)$ distributions. Non-directional asymmetry $\left(\mathrm{MS}_{\mathrm{SJ}}\right)$ is tested over measurement error and directional asymmetry is tested over non-directional asymmetry. Size or shape variation is not tested in this study as the size correction transformation employed resulted in $\mathrm{MS}_{\mathrm{J}}=0$ for all measures. In the absence of anti-symmetry, FA can be quantified for a BL measure for a tooth as:

$$
\mathrm{s}_{\mathrm{i}}^{2}=\left(\mathrm{MS}_{\mathrm{SJ}}-\mathrm{MS}_{\mathrm{M}}\right) / 2
$$

Comparisons of FA between the Late Archaic and Pearson Village samples used an F-test (ratio of $\mathrm{s}^{2}{ }_{\mathrm{i}}$ s) with degrees of freedom for each $\mathrm{s}^{2}$ given by:

$$
\left(\mathrm{MS}_{\mathrm{SJ}}-\mathrm{MS}_{\mathrm{M}}\right)^{2} /\left(\left(\mathrm{MS}_{\mathrm{S}}\right)^{2} / \mathrm{J}-1\right)+\left(\left(\mathrm{MS}_{\mathrm{M}}\right)^{2} / \mathrm{SJ}\right) \text {. }
$$

Associations between relative duration of the precalicification stage of tooth development (Mizoguchi, 1980), relative tooth size variation (coefficient of variation), and FA $\left(\mathrm{s}_{\mathrm{i}}^{2}\right)$ were tested using Spearman's rank correlation coefficient (Sokal and Rohlf, 1981). Associations were obtained within each sample as well as between samples. All analyses were performed using NCSS (Hintze, 1992).

\section{RESULTS}

Tables 2 and 3 contain the descriptive statistics and a measurement error estimate for the first and second BL measure in the maxillary and mandibular teeth of the Late Archaic and the Pearson samples. Overall relative variation of the BL diameters as measured by the coefficient of variation averages $2.6 \%$ higher in the Pearson Village sample. However, no variances are significantly different in the two samples (F-test; Sokal and Rohlf, 1981). Mean BL diameters are consistently smaller in the Pearson sample $(3.4 \%$ overall) with the maxillary teeth $(3.7 \%)$ somewhat smaller than the mandibular teeth (3.1\%). Tests of the differences in the means of the BL diameters (t-test; Sokal and Rohlf, 1981) revealed that the Pearson Village sample exhibited significantly smaller BL diameters for all teeth except the maxillary first molar and the lower canine, which showed no differences between the samples.

The BL diameters are for the most part normally distributed in both samples. In the Late Archaic sample only the upper anterior premolar (both measures, right and left), upper lateral incisor (both measures, left side), and upper posterior premolar (both measures, right side) show departures from normality. In the Pearson Village sample only the upper second molar (both measures, right side) and lower lateral incisor (first measure, right side) show departures from normality.

Measurement error in the Late Archaic sample (0.06$0.09 \mathrm{~mm}$ ) is in all cases greater than in the Pearson Village sample $(0.03-0.04 \mathrm{~mm})$ although the $95 \%$ confidence intervals overlap in most cases. The difference in measurement error is due primarily to the differences in the instrument accuracy (see Measurement).

Table 4 contains the results of the analyses of the distributions of $\left(\mathrm{R}_{\mathrm{i}}-\mathrm{L}_{\mathrm{i}}\right)$ for the first and second measures in both samples. The Late Archaic sample exhibited some departures from normal $\left(R_{i}-L_{i}\right)$ distributions for four measures: the upper canine showed a slight $(p=0.04)$ right skewness (measure 1$)$, the lower lateral incisor showed a slight leptokurtosis $(\mathrm{p}=0.02)$ for measurement 2 , the upper first molar was leptokurtotic $(p=0.06)$ for the second measure only, and the lower second molar showed a slight leptokurtosis $(p=0.04)$ for the first measure and slight skewness $(p=0.005)$ and leptokurtosis $(p=0.01)$ for the second measure.

In the Pearson Village sample, six teeth exhibited some departure from normality: the upper central incisor $(p=0.04)$ and the lower second molar $(p=0.03)$ showed slightly left skewed distributions for one of the two measures, the lower first molar showed a left skewness for both the first $(\mathrm{p}=0.02)$ and second $(\mathrm{p}=$

\begin{tabular}{|c|c|c|c|c|}
\hline Source of Variation & $\mathrm{df}$ & Mean Square & Expected Mean Square & Interpretation \\
\hline Sides (S) & (S-1) & $\mathrm{MS}_{\mathrm{s}}$ & $\sigma_{m}^{2}+M\left(\sigma_{i}^{2}+\left(J / s_{-1}\right) \sum \alpha^{2}\right.$ & Directional asymmetry \\
\hline Individuals (J) & $(\mathrm{J}-1)$ & $\mathrm{MS}_{\mathrm{J}}^{\mathrm{s}}$ & $\sigma_{m}^{2}+M\left(\sigma_{i}^{2}+S \sigma_{J}^{2}\right)$ & Shape or size variation \\
\hline Remainder & $(\mathrm{S}-1)(\mathrm{J}-1)$ & $\mathrm{MS}_{\mathrm{SI}}$ & $\sigma_{m}^{2 m}+M \sigma_{i}^{2}$ & Non directional asymmetry \\
\hline Measurement (M) & SJ(M-1) & $\mathrm{MS}_{\mathrm{M}}$ & $\sigma_{\mathrm{m}}^{211}$ & Measurement error \\
\hline
\end{tabular}

TABLE 1. Anova model; see text for discussion 
TABLE 2. Descriptive statistics and measurement error for the buccolingual diameters of the maxillary teeth in the Archaic and Pearson samples

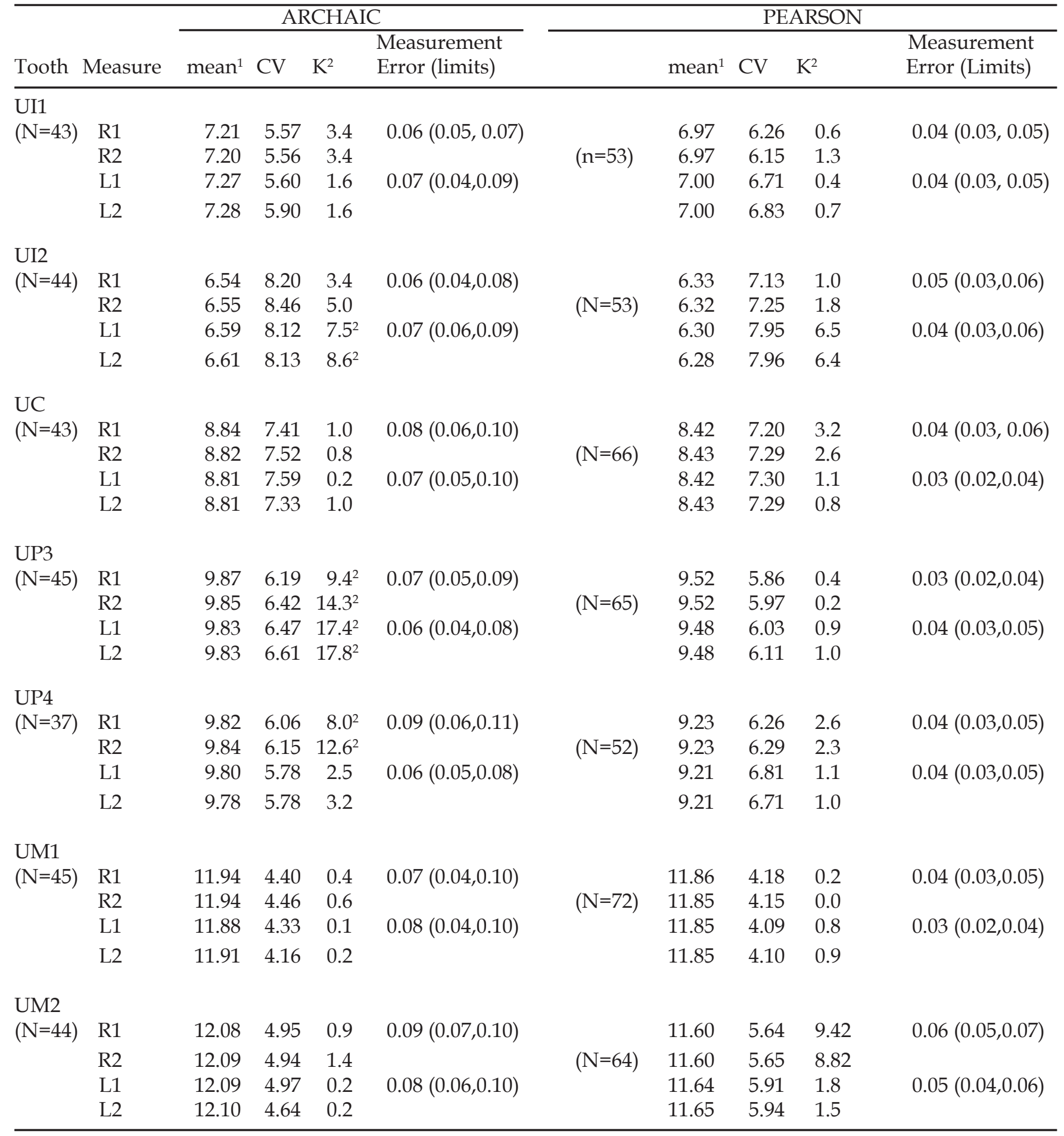

${ }^{1} \mathrm{CV}$ is coefficient of variation, $\mathrm{K}^{2}$ is omnibus normality test (D'Agostino, 1990), error is $\Sigma|\mathrm{R}-\mathrm{L}| / \mathrm{n}$, limits is $95 \%$ limits of error.

${ }^{2} \mathrm{P}<0.05$.

$0.002)$ measures, the upper first molar first measure $(p=$ $0.03)$ and lower central incisor both measures $(p=0.03 ; p$ $=0.01$ ) showed slightly leptokurtic distributions, and the lower lateral incisor showed a slight right skewness $(\mathrm{p}=$ 0.03 ) for both measures.

Because there is no indication of platykurtosis in any distribution of signed differences and since signed differences are not limited to larger deviations in the cases of leptokurtosis, overall anti-symmetry is judged to be absent in the present samples. Since most deviations from normality are relatively minor these data appear to be suitable for the analysis of FA. 
TABLE 3. Descriptive statistics and measurement error for the buccolingual diameters of the mandibular teeth in the Archaic and Pearson samples

\begin{tabular}{|c|c|c|c|c|c|c|c|c|c|c|}
\hline \multirow[b]{2}{*}{ Tooth } & \multicolumn{5}{|c|}{ ARCHAIC } & \multicolumn{5}{|c|}{ PEARSON } \\
\hline & Measure & mean $^{1}$ & $\mathrm{CV}$ & $\mathrm{K}^{2}$ & $\begin{array}{l}\text { Measurement } \\
\text { Error (Limits) }\end{array}$ & & mean $^{1}$ & $\mathrm{CV}$ & $\mathrm{K}^{2}$ & $\begin{array}{l}\text { Measurement } \\
\text { Error (Limits) }\end{array}$ \\
\hline \multirow[t]{4}{*}{$\begin{array}{l}\text { LI1 } \\
(\mathrm{N}=39)\end{array}$} & $\mathrm{R} 1$ & 5.72 & 5.04 & 0.9 & $0.06(0.05,0.07)$ & \multirow{4}{*}{$(\mathrm{N}=61)$} & 5.58 & 5.39 & 1.0 & $0.03(0.02,0.04)$ \\
\hline & $\mathrm{R} 2$ & 5.70 & 5.15 & 1.7 & & & 5.58 & 5.41 & 0.6 & \\
\hline & L1 & 5.70 & 5.64 & 2.6 & $0.06(0.05,0.07)$ & & 5.59 & 5.42 & 0.1 & $0.04(0.03,0.06)$ \\
\hline & $\mathrm{L} 2$ & 5.68 & 5.57 & 2.3 & & & 5.59 & 5.44 & 0.2 & \\
\hline \multirow{5}{*}{$\begin{array}{l}\mathrm{LI} 2 \\
(\mathrm{~N}=44)\end{array}$} & & & & & & \multirow{5}{*}{$(\mathrm{N}=60)$} & & & & \\
\hline & $\mathrm{R} 1$ & 6.19 & 5.19 & 2.6 & $0.07(0.06,0.08)$ & & 6.00 & 5.18 & $6.5^{2}$ & $0.04(0.03,0.05)$ \\
\hline & $\mathrm{R} 2$ & 6.17 & 4.83 & 1.7 & & & 5.99 & 5.25 & 5.9 & \\
\hline & L1 & 6.18 & 4.63 & 1.7 & $0.07(0.05,0.09)$ & & 5.97 & 5.12 & 0.3 & $0.04(0.03,0.05)$ \\
\hline & L2 & 6.14 & 4.75 & 0.2 & & & 5.96 & 5.09 & 0.8 & \\
\hline \multirow{5}{*}{$\begin{array}{l}\mathrm{LC} \\
(\mathrm{N}=50)\end{array}$} & & & & & & \multirow{5}{*}{$(\mathrm{N}=63)$} & & & & \\
\hline & $\mathrm{R} 1$ & 7.86 & 7.01 & 0.3 & $0.06(0.04,0.07)$ & & 7.72 & 7.16 & 3.4 & $0.03(0.02,0.04)$ \\
\hline & $\mathrm{R} 2$ & 7.85 & 7.10 & 1.0 & & & 7.73 & 7.15 & 4.0 & \\
\hline & L1 & 7.90 & 7.83 & 0.6 & $0.07(0.04,0.09)$ & & 7.71 & 7.18 & 3.6 & $0.04(0.03,0.04)$ \\
\hline & L2 & 7.90 & 7.91 & 0.6 & & & 7.71 & 7.19 & 3.0 & \\
\hline \multirow{5}{*}{$\begin{array}{l}\mathrm{LP3} \\
(\mathrm{N}=45)\end{array}$} & & & & & & \multirow{5}{*}{$(\mathrm{N}=71)$} & & & & \\
\hline & $\mathrm{R} 1$ & 8.28 & 5.66 & 0.7 & $0.06(0.05,0.08)$ & & 7.86 & 6.61 & 0.7 & $0.04(0.03,0.05)$ \\
\hline & $\mathrm{R} 2$ & 8.29 & 5.57 & 0.2 & & & 7.86 & 6.62 & 0.6 & \\
\hline & L1 & 8.30 & 5.39 & 2.7 & $0.07(0.05,0.08)$ & & 7.87 & 5.90 & 0.2 & $0.04(0.03,0.05)$ \\
\hline & L2 & 8.31 & 5.34 & 2.6 & & & 7.87 & 5.88 & 0.6 & \\
\hline \multirow{5}{*}{$\begin{array}{l}\mathrm{LP} 4 \\
(\mathrm{~N}=47)\end{array}$} & & & & & & \multirow{5}{*}{$(\mathrm{N}=62)$} & & & & \\
\hline & $\mathrm{R} 1$ & 8.65 & 5.32 & 5.2 & $0.07(0.05,0.09)$ & & 8.30 & 5.91 & 0.6 & $0.04(0.03,0.05)$ \\
\hline & $\mathrm{R} 2$ & 8.66 & 5.50 & 3.9 & & & 8.29 & 5.85 & 1.2 & \\
\hline & L1 & 8.66 & 5.20 & 4.1 & $0.08(0.06,0.09)$ & & 8.34 & 5.71 & 0.1 & $0.04(0.03,0.05)$ \\
\hline & L2 & 8.66 & 5.27 & 5.7 & & & 8.33 & 5.74 & 0.1 & \\
\hline \multirow{5}{*}{$\begin{array}{l}\mathrm{LM} 1 \\
(\mathrm{~N}=53)\end{array}$} & & & & & & \multirow{5}{*}{$(\mathrm{N}=84)$} & & & & \\
\hline & R1 & 10.81 & 4.63 & 0.4 & $0.09(0.07,0.11)$ & & 10.63 & 4.65 & 1.1 & $0.04(0.03,0.05)$ \\
\hline & $\mathrm{R} 2$ & 10.83 & 4.76 & 0.7 & & & 10.62 & 4.55 & 1.0 & \\
\hline & L1 & 10.81 & 4.72 & 0.0 & $0.07(0.05,0.09)$ & & 10.69 & 4.61 & 1.9 & $0.04(0.03,0.05)$ \\
\hline & L2 & 10.83 & 4.65 & 0.4 & & & 10.68 & 4.60 & 2.5 & \\
\hline \multirow{5}{*}{$\begin{array}{l}\mathrm{LM} 2 \\
(\mathrm{~N}=45)\end{array}$} & & & & & & \multirow{5}{*}{$(\mathrm{N}=64)$} & & & & \\
\hline & $\mathrm{R} 1$ & 10.79 & 5.80 & 3.9 & $0.07(0.05,0.08)$ & & 10.35 & 4.93 & 1.0 & $0.04(0.03,0.05)$ \\
\hline & R2 & 10.80 & 5.87 & 3.5 & & & 10.35 & 5.00 & 1.0 & \\
\hline & L1 & 10.79 & 5.90 & 0.1 & $0.08(0.06,0.10)$ & & 10.39 & 5.40 & 0.7 & $0.04(0.03,0.05)$ \\
\hline & $\mathrm{L} 2$ & 10.83 & 5.68 & 0.5 & & & 10.39 & 5.30 & 0.2 & \\
\hline
\end{tabular}

${ }^{1} \mathrm{CV}$ is coefficient of variation, $\mathrm{K}^{2}$ is omnibus normality test (D'Agostino, 1990), error is $\Sigma|\mathrm{R}-\mathrm{L}| / \mathrm{n}$, limits is $95 \%$ limits of error. ${ }^{2} \mathrm{P}<0.05$.

The mean of the distribution of signed differences is significantly different than zero for three teeth (t-test): the upper central incisor and the upper first molar in the Archaic sample and lower first molar in the Pearson Village sample. In the Late Archaic sample the mean of the left upper central incisor is larger than the right $(\mathrm{p}=$ $0.03)$ while the right upper first molar is larger than the left $(p=0.002)$. For both of these teeth the differences are significant for the first measures only. In the Pearson Village sample the left lower first molar is larger than the right for both measures $(p=0.002 ; p=0.003)$. Directional asymmetry appears to be present at least for the Pearson Village lower first molar.

Tables 5 and 6 contain the results of the analysis of 
TABLE 4. Descriptive statistics for the distribution of $\left(R_{i}-L_{i}\right)$ in the Late Archaic and Pearson Village samples

\begin{tabular}{|c|c|c|c|c|c|c|c|c|c|c|c|c|c|c|c|c|c|}
\hline \multirow{3}{*}{\multicolumn{2}{|c|}{ Measure }} & \multicolumn{8}{|c|}{ Maxilla } & \multicolumn{8}{|c|}{ Mandible } \\
\hline & & \multicolumn{4}{|c|}{ ARCHAIC } & \multicolumn{4}{|c|}{ PEARSON } & \multicolumn{4}{|c|}{ ARCHAIC } & \multicolumn{4}{|c|}{ PEARSON } \\
\hline & & mean $^{1}$ & ${ }^{1} \mathrm{~g}_{1}$ & $\mathrm{~g}_{2}$ & $\mathrm{~K}^{2}$ & mean & $\mathrm{g}_{1}$ & $\mathrm{~g}_{2}$ & $\mathrm{~K}^{2}$ & mean & $\mathrm{g}_{1}$ & $\mathrm{~g}_{2}$ & $\mathrm{~K}^{2}$ & mean & $\mathrm{g}_{1}$ & $\mathrm{~g}_{2}$ & $\mathrm{~K}^{2}$ \\
\hline \multirow[t]{2}{*}{1} & R-L(1) & -0.06 & 0.17 & 0.70 & 1.4 & -0.03 & -0.44 & -0.17 & 1.9 & 0.02 & 0.31 & 1.24 & 3.1 & -0.01 & 0.41 & $2.58^{2}$ & 9.0 \\
\hline & R-L(2) & $-0.07^{2}$ & 0.19 & 1.10 & 2.5 & -0.03 & $-0.69^{2}$ & -0.12 & 4. & 0.02 & -0.24 & 1.59 & 3.7 & -0.01 & 0.53 & $1.93^{2}$ & 8.2 \\
\hline \multirow[t]{2}{*}{$\mathrm{I} 2$} & R-L(1) & -0.06 & -0.02 & 0.03 & 0.1 & 0.04 & -0.21 & 0.65 & 3.8 & 0.01 & -0.12 & 0.23 & 0.4 & 0.04 & $0.69^{2}$ & 1.07 & \\
\hline & $\mathrm{R}-\mathrm{L}(2)$ & -0.06 & 0.02 & 0.83 & 1.5 & 0.04 & -0.42 & 0.99 & 1.7 & 0.04 & 0.33 & $2.31^{2}$ & $6.2^{2}$ & 0.03 & $0.67^{2}$ & -0.15 & 4. \\
\hline \multirow[t]{2}{*}{ c } & R-L(1) & 0.03 & $0.74^{2}$ & 1.26 & $6.6^{2}$ & -0.01 & -0.34 & 1.13 & 4.2 & 0.04 & -0.45 & -0.16 & 1. & 0.01 & 0.07 & 0.90 & 2. \\
\hline & R-L(2) & 0.01 & 0.25 & 0.85 & 2.1 & 0.01 & 0.01 & 0.09 & 0.1 & -0.05 & -0.59 & -0.08 & 3.1 & 0.02 & -0.03 & 0.04 & 0 . \\
\hline \multirow[t]{2}{*}{ P3 } & R-L(1) & 0.04 & -0.32 & 0.01 & 0.9 & 0.04 & -0.09 & -0.37 & 0 & 0.02 & -0.18 & 0.96 & 2.1 & 0.00 & -0.06 & -0.15 & 0. \\
\hline & $\mathrm{R}-\mathrm{L}(2)$ & 0.01 & 0.13 & 0.09 & 0.3 & 0.04 & 0.10 & 0.06 & 0.2 & -0.02 & -0.16 & 0.11 & 0.4 & 0.01 & -0.03 & -0.35 & 0 . \\
\hline \multirow[t]{2}{*}{ P4 } & R-L(1) & 0.02 & -0.37 & -0.38 & 1.1 & 0.02 & -0.07 & 1.42 & 3.3 & -0.01 & -0.51 & 0.73 & 3.5 & -0.03 & -0.56 & 0.97 & 5.6 \\
\hline & R-L(2) & 0.06 & -0.60 & -0.39 & 2.6 & 0.02 & 0.13 & 1.12 & 2.6 & -0.01 & 0.45 & 1.40 & 4.7 & -0.03 & -0.50 & 0.20 & 3. \\
\hline \multirow[t]{2}{*}{ M1 } & R-L(1) & $0.06^{2}$ & 0.55 & 0.93 & 4.2 & 0.01 & 0.17 & 0.04 & & 0.00 & -0.04 & 0.44 & 6.7 & $-0.06^{2}$ & $-0.65^{2}$ & 0.83 & 7. \\
\hline & $\mathrm{R}-\mathrm{L}(2)$ & 0.03 & -0.60 & $3.15^{2}$ & $10.3^{2}$ & 0.00 & -0.42 & $1.65^{2}$ & $7.1^{2}$ & 0.01 & 0.28 & 0.69 & 2.1 & $-0.06^{2}$ & $-0.88^{2}$ & 0.79 & 11. \\
\hline \multirow[t]{2}{*}{ M2 } & R-L(1) & -0.01 & 0.37 & -0.34 & 1.3 & -0.04 & -0.43 & 0.70 & 3.6 & 0.00 & 0.40 & $1.90^{2}$ & 5.7 & -0.04 & $-0.66^{2}$ & 0.96 & 7. \\
\hline & R-L(2) & -0.01 & 0.20 & 0.30 & 0.8 & -0.04 & -0.28 & 0.72 & 2.5 & -0.03 & $1.08^{2}$ & $3.11^{2}$ & $15.2^{2}$ & -0.04 & -0.56 & 0.66 & 4.8 \\
\hline
\end{tabular}

${ }^{1} \mathrm{~g}_{1}$ is skewness, $\mathrm{g}_{2}$ is kurtosis, and $\mathrm{K}^{2}$ is omnibus normality test ${ }^{2} \mathrm{P}<0.05$

variance (anova) for the maxillary and mandibular BL diameters respectively. The size correction transformation resulted in all cases in eliminating the size-shape (individual) source of variation (MS $=0)$. Thus three sources of variation remain: sides, fluctuating asymmetry (= non-directional asymmetry as anti-symmetry is not present), and measurement error.

Directional asymmetry (sides) as measured by the anovas is significant in four Late Archaic teeth and two Pearson Village teeth. In the Late Archaic sample the right upper first molar is larger than the left, while for the upper lateral and central incisors and lower canines, the left sides are larger than the right (these four teeth also show the greatest $\left(\mathrm{R}_{\mathrm{i}}-\mathrm{L}_{\mathrm{i}}\right)$ differences in Table 4 although all are not significant). In the Pearson sample the lower left first molar is larger than the right while the lower right lateral incisor is larger than the left.

FA is significantly greater than measurement error for all teeth in both samples. The Late Archaic sample exhibits significantly greater variance components $\left(\mathrm{s}_{\mathrm{i}}{ }^{2}\right)$ for the upper canine and lower lateral incisor while the Pearson Village sample exhibits greater variance components for the upper lateral incisor and first molar.

Measurement error $\left(\mathrm{s}_{\mathrm{m}}{ }^{2}\right)$ as a percentage of $\left(\mathrm{s}_{\mathrm{i}}{ }^{2}+\right.$ $\mathrm{s}_{\mathrm{m}}{ }^{2}$ ) ranges between 5.2 and 39.2\% for the Late Archaic sample with most values in the $5-15 \%$ range. In the Pearson Village sample, in which measurement error was lower, the corresponding values range between 2.7 and $12.1 \%$ with most values in the $3-10 \%$ range.

Spearman rank correlation coefficients between the coefficients of variation $(\mathrm{cv})$, variance components of FA $\left(\mathrm{s}_{\mathrm{i}}{ }^{2}\right)$ and the relative time a tooth spends in soft tissue stages of crown development (Mizoguchi, 1980) are contained in Table 7. In the Archaic sample FA is significantly correlated with CV (positive) while in the Pearson Village sample FA is significantly correlated with CV (positive) and time spent in soft tissue development (positive). Late Archaic FA is positively correlated with Pearson Village FA and CV but the Pearson Village FA is positively associated only with Late Archaic FA.

\section{DISCUSSION}

The Late Archaic and Pearson Village samples each exhibit directional and fluctuating asymmetry. While FA is present in all teeth in both samples, directional asymmetry is limited to four teeth in the Late Archaic sample (upper first molar, central and lateral incisors, and lower canine) and only two teeth in the Pearson Village sample (lower first molar and lateral incisor). Harris (1992) and Townsend and Farmer (1998) have found directional asymmetry in the permanent and deciduous teeth respectively and have noted that there appears to be a tendency for right side dominance in one arch to be associated with left side dominance in the opposing 
TABLE 5. Analysis of variance for maxillay teeth in the Late Archaic and Pearson Village

\begin{tabular}{|c|c|c|c|c|c|c|c|c|c|c|c|c|c|}
\hline \multirow{2}{*}{\multicolumn{2}{|c|}{ Tooth Source }} & \multicolumn{6}{|c|}{ ARCHAIC } & \multicolumn{6}{|c|}{ PEARSON } \\
\hline & & \multirow{2}{*}{$\frac{\mathrm{df}}{1}$} & \multirow{2}{*}{$\frac{\mathrm{SSQ}^{4}}{33.67}$} & \multirow{2}{*}{$\frac{\text { MSQ }}{33.67}$} & \multirow{2}{*}{$\frac{F}{4.11^{2}}$} & \multirow[t]{2}{*}{$\mathrm{s}_{\mathrm{i}}^{2}$} & \multirow[t]{2}{*}{$\mathrm{df}$} & \multirow{2}{*}{$\frac{\mathrm{df}}{1}$} & \multirow{2}{*}{$\begin{array}{r}\mathrm{SSQ}^{4} \\
7.45\end{array}$} & \multirow{2}{*}{$\frac{\text { MSQ }}{7.45}$} & \multirow{2}{*}{$\frac{F}{1.29}$} & \multirow[t]{2}{*}{$\mathrm{s}_{\mathrm{i}}^{2}$} & \multirow[t]{2}{*}{$\mathrm{df}$} \\
\hline UI1 & Sides & & & & & & & & & & & & \\
\hline & Individuals & 42 & 0 & 0 & 0 & & & 52 & 0 & 0 & 0 & & \\
\hline & Remainder & 42 & 343.4 & 8.18 & $28.85^{*}$ & 3.95 & 39 & 52 & 299.2 & 5.75 & $43.20^{*}$ & 2.81 & 50 \\
\hline & Error & 86 & 24.38 & 0.28 & & & & 106 & 14.11 & 0.13 & & & \\
\hline \multirow{4}{*}{ UI2 } & Sides & 1 & 37.58 & 37.58 & $4.04^{2}$ & & & 1 & 25.23 & 25.23 & 1.50 & & \\
\hline & Individuals & 43 & 0 & 0 & 0 & & & 52 & 0 & 0 & 0 & & \\
\hline & Remainder & 43 & 399.6 & 9.29 & $21.45^{*}$ & 4.43 & 40 & 52 & 874.0 & 16.81 & $57.37^{*}$ & 8.263 & 50 \\
\hline & Error & 88 & 38.13 & 0.43 & & & & 106 & 31.01 & 0.29 & & & \\
\hline \multirow[t]{4}{*}{$\mathrm{UC}$} & Sides & 1 & 2.17 & 2.17 & 0.24 & & & 1 & 0.01 & 0.01 & 0 & & \\
\hline & Individuals & 42 & 0 & 0 & 0 & & & 65 & 0 & 0 & 0 & & \\
\hline & Remainder & 42 & 375.9 & 8.95 & $23.08^{*}$ & $4.28^{2}$ & 39 & 65 & 273.5 & 4.21 & $38.27^{*}$ & 2.05 & 62 \\
\hline & Error & 86 & 33.36 & 0.39 & & & & 132 & 14.68 & 0.11 & & & \\
\hline \multirow{4}{*}{ UP3 } & Sides & 1 & 3.43 & 3.43 & 0.71 & & & 1 & 11.24 & 11.24 & 3.41 & & \\
\hline & Individuals & 44 & 0 & 0 & 0 & & & 64 & 0 & 0 & & & \\
\hline & Remainder & 44 & 213.2 & 4.85 & $37.30^{*}$ & 2.36 & 37 & 64 & 211.0 & 3.30 & $47.14^{*}$ & 1.62 & 61 \\
\hline & Error & 90 & 11.83 & 0.13 & & & & 130 & 8.76 & 0.07 & & & \\
\hline \multirow{4}{*}{ UP4 } & Sides & 1 & 5.31 & 5.31 & 0.72 & & & 1 & 3.24 & 3.24 & 0.44 & & \\
\hline & Individuals & 36 & 0 & 0 & 0 & & & 51 & 0 & 0 & 0 & & \\
\hline & Remainder & 36 & 266.7 & 7.41 & $28.50^{*}$ & 3.58 & 34 & 51 & 376.8 & 7.39 & $70.9^{*}$ & 3.64 & 50 \\
\hline & Error & 74 & 18.95 & 0.26 & & & & 104 & 10.84 & 0.10 & & & \\
\hline \multirow{4}{*}{\multicolumn{2}{|c|}{$\begin{array}{l}\text { UM1 Sides } \\
\text { Individuals } \\
\text { Remainder } \\
\text { Error }\end{array}$}} & 1 & 5.38 & 5.38 & $5.03^{2}$ & & & 1 & 0.18 & 0.18 & 0.11 & & \\
\hline & & 44 & 0 & 0 & 0 & & & 71 & 0 & 0 & 0 & & \\
\hline & & 44 & 46.98 & 1.07 & $4.13^{*}$ & 0.40 & 25 & 71 & 109.0 & 1.53 & $24.50^{*}$ & $0.74^{2}$ & 65 \\
\hline & & 90 & 22.34 & 0.26 & & & & 144 & 9.02 & 0.06 & & & \\
\hline \multirow{4}{*}{\multicolumn{2}{|c|}{$\begin{array}{l}\text { UM2 Sides } \\
\text { Individuals } \\
\text { Remainder } \\
\text { Error }\end{array}$}} & 1 & 0.19 & 0.19 & 0.04 & & & 1 & 9.05 & 9.05 & 1.87 & & \\
\hline & & 43 & 0 & 0 & 0 & & & 63 & 0 & 0 & 0 & & \\
\hline & & 43 & 182.7 & 4.25 & $19.31^{*}$ & 2.02 & 39 & 63 & 303.6 & 4.82 & $43.81^{*}$ & 2.36 & 60 \\
\hline & & 88 & 19.15 & 0.22 & & & & 128 & 13.52 & 0.11 & & & \\
\hline
\end{tabular}

${ }^{*} \mathrm{P}<0.001$

${ }^{1} \mathrm{P} \sim 0.05$

${ }^{2} 0.05>\mathrm{P}>0.025$

${ }^{3}$ Pearson $\mathrm{s}_{i}^{2}>$ Archaic $\mathrm{s}_{\mathrm{i}}^{2} \mathrm{~F}=1.56, \mathrm{P} \sim 0.025$

${ }^{4}$ Archaic $\mathrm{s}_{i}^{2}>$ Pearson $\mathrm{s}_{i}^{2} \mathrm{~F}=2.09, \mathrm{P} \sim 0.005$

${ }^{5}$ Pearson $\mathrm{s}_{\mathrm{i}}^{2}>$ Archaic $\mathrm{s}_{\mathrm{i}}^{2} \mathrm{~F}=1.85, \mathrm{P} \sim 0.025$

${ }^{6} \mathrm{SSQ}, \mathrm{MSQ}$, and $\mathrm{s}_{\mathrm{i}}^{2} \times 10^{4}$

arch. This tendency for opposing arch dominance is not exhibited by either the Late Archaic or the Pearson Village sample. In the Pearson Village sample only mandibular teeth exhibited directional asymmetry (one right and one left dominant) while in the Late Archaic sample only one mandibular tooth (canine, L > $\mathrm{R}$ ) and three maxillary teeth (first molar, R > L; central incisor, $\mathrm{L}>\mathrm{R}$; lateral incisor, $\mathrm{L}>\mathrm{R}$ ) exhibited directional asymmetry. One possible pattern exhibited by the Late Archaic and Pearson Village samples is all teeth that exhibit directional asymmetry are relatively early developing permanent teeth. Harris (1992) proposed that the degree of directional asymmetry may be related to the level of developmental stress in a population and may result from differences in developmental timing between antimeres. Sharma et al. (1986) suggested that environmental or genetic stress could lead to unilateral acceleration of mitotic activity in developing enamel organs yielding directional asymmetry. While early development was likely a stressful period for children in the Late Archaic and Pearson Village populations an association between increased stress (as measured by FA) and directional asymmetry is absent. Of the six teeth that show directional asymmetry three (upper first molar and lateral incisor and lower lateral incisor) exhibit directional asymmetry in the sample that shows significantly less FA for that tooth. In the other three cases of directional asymmetry the samples 
TABLE 6. Analysis of variance for mandibular teeth in the Late Archaic and Pearson Village

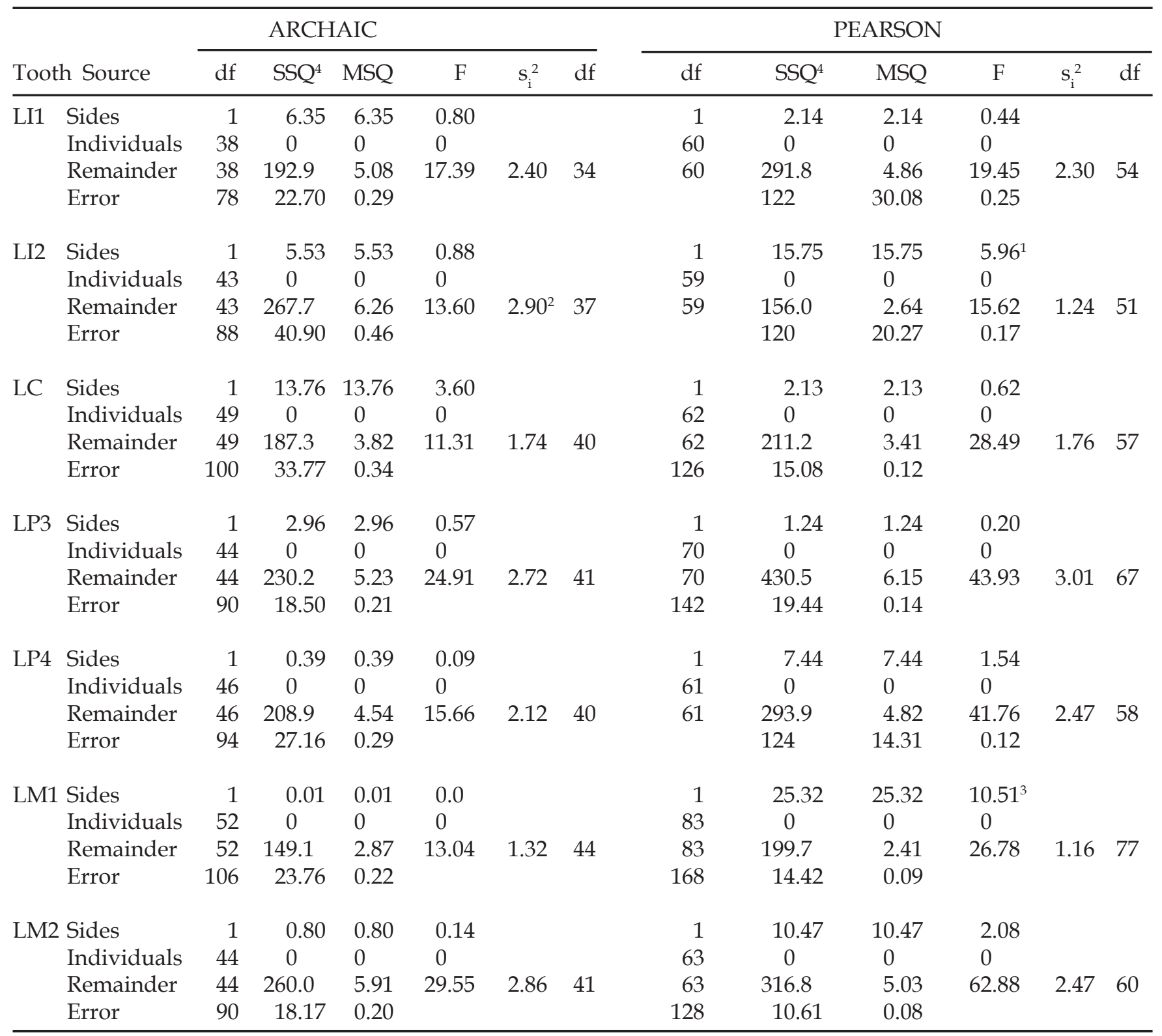

${ }^{1} 0.025>\mathrm{P}>0.025$

${ }^{2}$ Archaic $s_{i}^{2}>$ Pearson $s_{i}^{2}$

${ }^{3} \mathrm{P}>0.05$

${ }^{4} \mathrm{SSQ}, \mathrm{MSQ}$, and $\mathrm{s}_{\mathrm{i}}^{2} \times 10^{4}$

show no differences in FA. Although scenarios could be proposed to explain these data on directional asymmetry, for example that the presence of increased FA masks the presence of directional asymmetry, I think Townsend and Farmer (1998:253) summarized the current situation very well when they stated:

Although it would seem that directional dental asymmetry is not merely a statistical artifact, its exact nature and causes remain to be solved. So too does the question of whether there is any relationship between fluctuating and directional forms of dental asymmetry.
Fluctuating asymmetry is present for all teeth in both samples. However, contrary to expectations concerning the differences in environmental stress levels between foragers and agriculturalists, the Pearson Village agriculturalists do not show a greater level of FA compared to the Late Archaic foragers. The average FA $\left(\mathrm{s}_{\mathrm{i}}{ }^{2}\right)$ for all 14 teeth in the Late Archaic sample is virtually identical to that in the Pearson Village sample, 2.65 and $2.56\left(\times 10^{-4}\right)$ respectively. Only four teeth show significant differences between the samples with the Late Archaic sample showing greater FA for two teeth (upper canine and lower lateral incisor) and the Pearson sample showing greater FA also for two teeth (upper first molar and lateral incisor). The lack of an indication of increased developmental stress in the Pearson Village agriculturalists is likely due to the fact that maize 
TABLE 7. Spearman rank correlation coefficients between $F A, c v$ (relative variability) and duration spent in soft tissue development

\begin{tabular}{rrlll}
\hline & & CV & FA & SOFT \\
(A) & CV & --- & $0.62^{2}$ & 0.47 \\
& FA & $0.60^{1}$ & -- & $0.65^{3}$ \\
& SOFT & 0.46 & 0.24 & -- \\
& & \multicolumn{3}{c}{ Pearson Village } \\
& \multicolumn{3}{c}{ CV } & FA \\
& & & $0.88^{4}$ & 0.50 \\
(B) ARCHAIC & CV & FA & $0.61^{5}$ & $0.64^{6}$ \\
& &
\end{tabular}

(A): Pearson Village above diagonal, Archaic below diagonal

1. $\mathrm{P}=0.024$

2. $\mathrm{P}=0.018$

3. $\mathrm{P}=0.012$

4. $\mathrm{P}<0.0001$

5. $\mathrm{P}=0.020$

6. $\mathrm{P}=0.014$

agriculture was adopted late in prehistory (ca. 1000 BP) by Ohio Valley and lower Great Lakes populations and a heavy reliance on hunting and gathering as well as agriculture characterized the entire Late Prehistoric period (ca. 1000-350 BP). The transition to a full agricultural subsistence was probably never completely realized in this region. A survey of skeletal and dental stress indicators in Late Archaic and Late Prehistoric populations of the region suggests that while stress is indicated to some degree for all populations the relatively low prevalence of pathological conditions indicates that stress levels were not elevated. Aside from dental lesions which increase dramatically in the Late Prehistoric period, other pathological conditions as well as indicators such as growth rates and adult stature show only minor differences among the populations. These results in toto suggest that general life-style patterns did not vary greatly in the region over this time span and even after the introduction of maize agriculture, overall environmental stress was not elevated to the degree that would result in increased fluctuating dental asymmetry (Sciulli and Oberly, 2002).

The similarity between the Late Archaic and Pearson Village samples also extends to the relationship of FA, relative variation $(\mathrm{CV})$ and time spent in soft tissue development. In both the Late Archaic and Pearson Village samples FA $\left(\mathrm{s}_{\mathrm{i}}^{2}\right)$ is significantly correlated at about the same magnitude with relative variation, teeth displaying greater crown size variability also tend to show greater FA. Relative variation is strongly correlated between the two samples and FA is significantly correlated as well.

The observation that teeth with greater relative variation also tend to have greater $\mathrm{FA}$ has been suggested to be associated with the duration of soft tissue development. It is proposed that teeth that spend longer periods in soft tissue development during which they can be affected by environmental disturbances show greater relative variation and FA (Mizoguchi, 1983). In the Pearson Village sample FA is significantly associated with the duration of soft tissue development (Mizoguchi, 1983) but Archaic FA, Archaic CV and Pearson CV are not significantly correlated with the duration of soft tissue development. All of the statistically insignificant rank correlations with duration of soft tissue development except for Archaic FA are relatively large in magnitude and the insignificant correlations may be the result of using durations of soft tissue development that are only approximate for the prehistoric populations.

\section{LITERATURE CITED}

Ailbert P, Fel-Claire F, Manolakou K, Britton-Davidian J, Auffray JC. 1997. Developmental stability, fitness, and trait size in laboratory hybrids between European subspecies of the house mouse. Evolution 51:1284-1295.

Bailit HL, Workman PL, Niswander JD, MacLean CJ. 1970. Dental asymmetry as an indicator of genetic and environmental conditions in human populations. Hum Biol 42:626-638

Bowen J. 1978. The Eiden Phase component of Pearson Village. Ohio Arch 28:12-13.

Bowen J. 1991. The Late Prehistory of Northwestern Ohio. Ph.D. dissertation, The Ohio State University, Columbus.

Clarke GM. 1992 Fluctuating asymmetry: a technique for measuring developmental stress of genetic and environmental origin. Acta Zool Fenn 191:31-35.

Cohen MN, Armelagos GJ. 1984. Paleopathology at the origin of agriculture. New York: Academic Press.

Cohen MN. 1989. Health and the rise of civilization. New Haven: Yale University Press.

Cook DC. 1984. Subsistence and health in the lower Illinois Valley: osteological evidence. In: Cohen MN, Armelagos GJ, editors. Paleopathology at the origin of agriculture. New York: Academic Press. p 235-269.

D'Agostino RB, Belanger A, D'Agostino RB Jr. 1990. A suggestion for using powerful and informative tests of normality. Amer Statistician 44:316-321.

Dobzhansky T. 1970. Genetics of the evolutionary process. New York: Columbia University Press.

Doyle W,J Johnston O. 1977. On the meaning of increased fluctuating asymmetry: a cross-populational study. Am J Phys Anthropol 46:127-134.

DiBennardo R, Bailit HL. 1978. Stress and dental asymmetry in a population of Japanese children. Am J Phys Anthropol 48:89-94.

Farmer V, Townsend G. 1993. Crown size variability in the deciduous dentition of South African children. Am J Hum Biol 5:681-690.

Freeman DC, Graham JH, Byrd DW, McArthur ED, Turner WA. 1995. Narrow hybrid gene between 
two subspecies of big sagebrush, Artemisia tridentale (Asteraceac). III developmental instability. Am J Bot 82:1144-1152.

Goodman AH, Armelagos G. 1989. Infant and childhood morbidity and mortality risks in archaeological populations. World Arch 21:225-243.

Graham JH. 1992. Genomic coadaptation and developmental stability in hybrid zones. Acta Zool Fenn 191:121-131.

Graham JH, Freeman DC, Emlen JM. 1993. Antisymmetry, directional asymmetry, and dynamic morphogenesis. Genetica 89:121-137.

Harris EF. 1992. Laterality in human odontometrics: analysis of a contemporary American White series. In: Lukacs JR, editor. Culture, ecology, and dental anthropology. Delhi: Kamla-Raj. p 157-170.

Harris EF, Nweeia MT. 1980. Dental asymmetry as a measure of environmental stress in the Ticuna Indians of Columbia. Am J Phys Anthropol 53:133142.

Hintze JL. 1992. Number cruncher statistical system. Kaysville, Utah: Dr. Jerry L. Hintze.

Hochwender CG, Fritz RS. 1999. Fluctuating asymmetry in a Salix hybrid system: the importance of genetic versus environmental causes. Evolution 53:408-416.

Hurtado L, Castrezana S, Mateos M, McLaurin D, Tello MK, Marrkow TA. 1997. Developmental stability and environmental stress in natural populations of Drosophila pechea. Ecotoxicology 6:233-238.

Jantz RL, Meadows L. 1995. Population structure of Algonkian speakers. Hum Biol 67:375-386.

Kieser JA, Groeneveld HT, Preston C B. 1986. Fluctuating dental asymmetry as a measure of odontometric canalization in man. Am J Phys Anthropol 71:437444.

Kieser JA, Groenveld HT. 1988. Fluctuating odontometric asymmetry in an urban South African population. J Dent Res 67:1200-1205.

Klingenberg P, Nijhout HF. 1999. Genetics of fluctuating asymmetry: a developmental model of developmental instability. Evolution 53:358-375.

Langdon SP. 1995. Biological relationships among the Iroquois. Hum Biol 67:355-374.

Larsen CS. 1995. Biological changes in human populations with agriculture. Ann Rev Anth 24: 185-213.

Markow TA, Ricker JP. 1991. Developmental stability in hybrids between the sibling species pair Drosophila melanogaster and Drosophila simulans. Genetica 84: 115-121.

Mather K. 1973. Polygenic inheritance and natural selection. Biol Rev 18:32-64.

Mitton JB. 1994. Enzyme heterozygosity, metabolism, and developmental stability. In: Markow TA, editor. Developmental instability: its origins and evolutionary implications. Dordrecht, the Netherlands: Kluwer Academic Publishers. p 49-67.
Mizoguchi Y. 1980. Factor analysis of environmental variation in the permanent dentition. Bull Natl Sci Mus (Tokyo) 6:29-46.

Mizoguchi Y. 1983. Influences of the earlier developing teeth upon the later developing teeth. Bull Natl Sci Mus (Tokyo) 9:33-45.

Mizoguchi Y. 1986. Correlated asymmetrics detected in tooth crown diameters of human permanent teeth. Bull Natl Sci Mus (Tokyo) 12:24-45.

Nosil P, Reimchen TE. 2001. Tarsal asymmetry, nutritional condition, and survival in water boatmen (Callicorixa vulnerata). Evolution 55:712-720.

Palmer AR, Strobeck C. 1986. Fluctuating asymmetry: measurement, analysis, patterns. Ann Rev Ecol Syst 17:391-422.

Parsons PA. 1990. Fluctuating asymmetry: an epigenetic measure of stress. Biol Rev 65:131-145.

Perzigian AJ. 1977. Fluctuating dental asymmetry: variation among skeletal populations. Am J Phys Anthropol 47:81-88.

Quetisch C, Sonster TA, Lindquist S. 2002. Hsp90 as a capacitor of phenotypic variation. Nature 417:618624.

Sharma K, Corruccini RS, Potter RHY. 1986. Genetic and environmental influences on bilateral dental asymmetry in Northwest Indian twins. Int J Anthropol 4:349-360.

Sciulli PW. 1997. Dental evolution in prehistoric Native Americans of the Ohio Valley area. I. Wear and pathology. Intl J Osteoarch 7:507-524.

Sciulli PW, Aument B 1987. Oaleodemography of the Duff Site (33LO111) Logan County Ohio. Midcont J Arch 2:117-144.

Sciulli PW, Schuck R, Giesen MJ. 1993. Terminal Late Archaic Mortuary Practices I Kirian Treglia (33AL39). Penna Arch 63:53-63.

Sciulli PW, Giesen MJ, Paine RR 1996. Paleodemography of the Pearson Complex (335SA9) Eiden Phase Cemetery. Arch East N America 24:81-94.

Sciulli PW, Schuck R 2001. Terminal Late Archaic Mortuary Practices II Boose. Penna Arch 71:29-42.

Sciulli PW, Oberly J. 2002. Native Americans in Eastern North America. In: Steckel RH, Rose JC, editors. The backbone of history: health and nutrition in the Western Hemisphere. New York: Cambridge University Press. p 440-480.

Siegel MI, Doyle NJ. 1975a. The different aspects of prenatal and postnatal audiogenic stress on fluctuating dental asymmetry. J Exp Zool 191:211214.

Siegel MI, Doyle NJ. 1975b. The effects of cold stress on fluctuating aasymmetry in the dentition of the house mouse. J Exp Zool 193:385-389.

Siegel MI, Doyle NJ. 1975c. Stress and fluctuating link asymmetry in various species of rodents. Growth 39: 363-369.

Smith BD. 1989. Origins of agriculture in Eastern North 
America. Science 246:1566-1571.

Smith BD. 1995. The emergence of agriculture. New York: Scientific-American Library.

Sokal RR, Rohlf F. 1987. Biometry, 2nd ed. New York: WH Freeman.

Steckel RH, Rose JC. 2002. The backbone of history: health and nutrition in the Western Hemishpere. New York: Cambridge Univeristy Press.

Strothers DM, Abel TJ. 1989. The position of the "Pearson complex" in the Late Prehistory of Ohio. Arch East N American 17:109-141.

Tatarek NE, Sciulli PW. 2000. Comparison of population structure in Ohio's Late Archaic and Late Prehistoric periods. Am J Phys Anthropol 112:363-376.

Townsend GC. 1981. Fluctuating asymmetry in the deciduous dentition of Australian Aboriginals. Hum Biol 52:661-673.
Townsend GC, Brown T. 1980. Dental asymmetry in the deciduous of South African children. In: Lukacs JR, editor. Human dental development, morphology, and pathology. Eugene: University of Oregon. p 245-258.

Van Valen L. 1962. A study of fluctuating asymmetry. Evolution 16:125-142.

Waddington $\mathrm{CH}$ 1957. The strategy of the genes. New York: Macmillian.

Waddington CH. 1960. Experiments or analyzing selection. Genet Res 1:140-150.

Watt WB. 1983. Adaptation at specific loci. II. Demographic and biochemical elements in the maintenance of the Colias PGI polymorphisms. Genetics 103:691-724.

Woods RE, Hercus MJ, Hoffman AA. 1998. Estimating the heritability of fluctuating asymmetry in field Drosophila. Evolution 52:816-824. 